\title{
Gangguan Keseimbangan Elektrolit Sesudah Kemoterapi Induksi Remisi pada Anak dengan Leukemia Limfoblastik Akut
}

\author{
Electrolyte Imbalance After Remission Induction Chemotherapy for Children with Acute \\ Lymphoblastic Leukemia
}

\author{
Susanto Nugroho \\ Laboratorium Ilmu Kesehatan Anak Fakultas Kedokteran Universitas Brawijaya Malang
}

\begin{abstract}
ABSTRAK
Gangguan keseimbangan elektrolit sering di jumpai pada leukemia limfoblastik akut pada anak karena proses leukemia, infiltrasi organ dan kematian sel akibat efek samping obat sitotoksik. Dari berbagai gangguan tersebut, gangguan keseimbangan elektrolit (hiperkalemi, hiperfosfatemi dan hipokalsemi) juga hyperuricemia dan azotemia paling sering ditemukan. Meskipun tidak mengancam jiwa, gangguan ini berpotensi menyebabkan efek kardiotoksi akibat kemoterapi seperti kematian mendadak karena aritmia malignant. Studi retrospektif ini dilakukan untuk mengevaluasi perubahan level serum elektrolit (potasium, kalsium, dan fosfor), asam urat dan ureum pada anak dengan ALL dan menerima induksi remisi kemoterapi menggunakan protokol Indonesia ALL-2006. Subjek penelitian adalah 34 anak dengan kasus baru ALL yang menerima remisi induksi kemoterapi. Terdapat peningkatan signifikan level serum potasium $(p=0,035)$ dan fosfor $(p=0,039)$, sebaliknya terdapat penurunan signifikan kadar calcium serum $(p=0,008)$. Disamping itu juga ditemukan peningkatan kadar asam urat dan ureum serum tetapi tidak signifikan. Dapat disimpulkan bahwa induksi remisi kemoterapi menggunakan protokol ALL 2006 dapat menyebabkan ketidakseimbangan elektrolit.
\end{abstract}

Kata Kunci : Anak, kemoterapi, ketidakseimbangan elektrolit, leukemia limfoblastik akut

\section{ABSTRACT}

Electrolyte disturbances are commonly seen in children with acute lymphoblasyic leukemia (ALL), due to either leukemic process, organ infiltration, and cell death adverse effects of cytotoxic drugs. Among these perturbation, electrolyte imbalance (e.g. hyperkalemia, hyperphosphatemia, and hypocalcemia) and also hyperuricemia and azotemia are more frequent. Although not life-threatening, these perturbances may lead to potential chemotherapy-related cardiotoxic effectsuch as sudden death due to malignant arrhythmias. This analytic retrospective study was conducted at Pediatric Hematology Oncology ward Dr. Saiful Anwar General Hospital Malang to evaluate changing in electrolyte serum levels (potassium, calcium, and phosphorus), uric acid and ureum in 34 children newly diagnosed ALL who receive remission induction chemotherapy with Indonesia Protocol-ALL 2006. There were significant increasing in potassium serum level ( $p=$ $0,035)$ and phosphorus serum level $(p=0,039)$, while calcium serum level was decresed significantly $(p=0,008)$. Otherwise, uric acid and ureum levels were increased but not significant. It can be concluded that remission induction chemotherapy with Protocol-ALL 2006 may lead to electrolyte imbalance.

Keywords: Acute lymphoblastic leukemia, chemotherapy, children, electrolyte imbalance

Jurnal Kedokteran Brawijaya, Vol. 26, No. 1, Februari 2010; Korespondensi: Susanto Nugroho. Laboratorium IImu Kesehatan Anak Rumah Sakit Saiful Anwar Malang, Jl. Jaksa Agung Suprapto No. 2 Malang Tel. (0341) 366242 Email: susantonugroho.ns@gmail.com 


\section{PENDAHULUAN}

Leukemia limfoblastik akut (LLA) adalah keganasan yang paling sering ditemukan pada anak dan dapat mengenai seluruh sistem organ $(1,2)$. Insiden LLA adalah sekitar $25 \%$ dari seluruh keganasan pada anak berusia kurang dari 15 tahun. Dengan kemajuan pengobatan kemoterapi, angka kesembuhan LLA mengalami peningkatan secara dramatis dalam 10 tahun terakhir sehingga dapat mencapai $75 \%$ sampai $80 \%(1)$. Gangguan elektrolit dan metabolik yang timbul selama kemoterapi merupakan salah satu faktor yang berpengaruh terhadap keberhasilan pengobatan anak dengan LLA.

Gangguan elektrolit dan metabolik sering ditemukan pada pasien anak dengan keganasan hematologi termasuk LLA (3-5). Gangguan tersebut dapat disebabkan oleh proses leukemik, infiltrasi sel-sel leukemia ke organ (khususnya tulang) maupun lisis sel-sel leukemia akibat pemberian obat-obat sitostatika, dan dapat terjadi sebelum, selama maupun sesudah pemberian kemoterapi $(4,5)$. Beberapa hasil penelitian yang telah dipublikasi sebelumnya menunjukkan bahwa gangguan elektrolit dan metabolik yang sering ditemukan pada anak dengan leukemia limfoblastik akut antara lain hiperkalemia, hipokalsemia, hiperfosfatemia, hiperurisemia dan azotemia (4-6).

Kemoterapi menyebabkan lisis sel-sel leukemia, yang diikuti dengan pelepasan bahan-bahan intraseluler, seperti kalium, fosfat, kalsium dan asam nukleat. Karena kandungan fosfat dan kalium di dalam sel leukemia empat kali lebih banyak dibandingkan kandungan fosfat dan kalium di dalam limfosit matur, maka pelepasan fosfat dan kalium yang berlebihan akibat lisis sel-sel leukemia menyebabkan terjadinya hiperfosfatemia dan hiperkalemia. Hiperfosfatemia akan meningkatkan presipitasi kristal kalsium-fosfat di tubulus ginjal, sehingga menyebabkan terjadinya nefrokalsinosis, obstruksi urin dan deposit jaringan. Sebagai konsekuensi dari hiperfosfatemia dan presipitasi kalsium-fosfat dapat terjadi hipokalsemia dan menurunnya fungsi ginjal yang ditandai dengan adanya azotemia. Sedangkan asam nukleat purin yang dilepas ke ruang ekstraseluler akan mengalami degradasi menjadi xantin, yang kemudian dimetabolisme menjadi asam urat. Hiperurisemia akan timbul bila katabolisme purin melebihi kapasitas ekskresi ginjal (4-6).

Gangguan elektrolit tidak selalu disertai dengan gejala klinis, sehingga jarang memerlukan terapi. Meskipun tidak mengancam jiwa, tetapi gangguan elektrolit akibat pemberian kemoterapi berpotensi menimbulkan efek kardiotoksik (chemotherapy-related cardiotoxic) dan nefropati yang berlanjut menjadi gagal ginjal akut. Pada kenyataannya, beberapa laporan kasus menunjukkan bahwa komplikasi fatal seperti kematian mendadak akibat aritmia atau disritmia malignant dapat terjadi pada pasien leukemia sebagai efek sinergistik antara obat sitostatika dan kelainan elektrolit $(6,7)$.

Penelitian ini dilakukan dengan tujuan untuk mengetahui perubahan kadar elektrolit (kalium, kalsium, dan fosfat), asam urat dan ureum serum yang terjadi pada pasien anak dengan LLA yang mendapatkan kemoterapi induksi remisi dengan menggunakan Indonesia Protocol-ALL 2006. Perubahan maupun gangguan keseimbangan elektrolit yang terjadi selama kemoterapi perlu mendapatkan terapi untuk mencegah komplikasi, sehingga dapat meningkatkan angka kesembuhan.

\section{METODE}

Penelitian ini adalah penelitian retrospektif analitik dengan menggunakan data sekunder berupa rekam medik pasien. Subyek meliputi pasien anak baru yang telah didiagnosis leukemia limfoblastik akut (LLA) yang dirawat di bangsal Hematologi-Onkologi Anak RSU Dr. Saiful Anwar selama bulan Januari 2008 sampai dengan Juni 2009. Diagnosis definitif LLA ditegakkan berdasarkan hasil pemeriksaan aspirasi sumsum tulang.

Penegakan diagnosis, penentuan kelompok risiko dan pemberian kemoterapi dilakukan oleh peneliti. Sebanyak 34 pasien yang memiliki data klinis, pemeriksaan laboratorium dan penunjang serta kemoterapi induksi remisi (selama minggu 0 sampai 6) yang lengkap diikutkan sebagai subjek dalam penelitian ini.

Dilakukan pencatatan data pasien saat inklusi (sebelum kemoterapi) meliputi umur, jenis kelamin, tipe LLA (L-1 atau L-2), pengelompokan faktor risiko (kelompok risiko standar atau risiko tinggi), serta data hematologi dasar meliputi kadar hemoglobin ( $\mathrm{Hb})$, hitung leukosit dan hitung trombosit. Pengambilan sampel darah dilakukan dua kali, yaitu sebelum (hari 0) dan sesudah (hari 49) kemoterapi induksi remisi untuk pengukuran kadar kalium (K), kalsium (Ca) dan fosfat (P) serum di Laboratorium Patologi Klinik RSU Dr. Saiful Anwar. Sebagai tambahan, dilakukan pemeriksaan kadar ureum dan asam urat darah pada hari 0 dan hari 49.

Untuk pemilihan protokol kemoterapi, pasien dikelompokkan dalam kelompok risiko standar dan risiko tinggi berdasarkan kriteria umur, jenis kelamin, hitung leukosit pada saat diagnosis ditegakkan dan infiltrasi sel blast ke dalam cairan serebrospinal (dengan pemeriksaan pungsi lumbal). Seluruh pasien mendapatkan kemoterapi dengan menggunakan Indonesia Protocol-ALL 2006. Kemoterapi induksi remisi dilakukan selama 7 minggu dengan 5 macam obat sitostatika, yaitu Vincristine 1,5 $\mathrm{mg} / \mathrm{m} 3 / \mathrm{minggu}$ secara intravena (pada minggu 1-6), Daunorubicin $30 \mathrm{mg} / \mathrm{m} 3 / \mathrm{minggu}$ secara intravena (pada minggu 1-4), L-Asparaginase $6000 \mathrm{U} / \mathrm{m} 3$ secara intravena 3 kali/minggu alternate day (pada minggu 4-5), Methotrexate 6-12 mg (tergantung umur) dan Dexamethason 0,6-1 mg (tergantung umur) secara intratekal pada minggu 0, 2 dan 4, serta Dexamethason secara oral. Pada protokol risiko standar diberikan Dexamethason oral $4 \mathrm{mg} / \mathrm{m} 3 /$ hari mulai minggu 1 sampai 6, sedangkan pada protokol risiko tinggi diberikan Dexamethason oral $6 \mathrm{mg} / \mathrm{m3} /$ hari mulai minggu 0 sampai 6.

Data dianalisis menggunakan paired t-test menggunakan program SPSS 13.0 untuk menilai kemaknaan secara statistik perubahan kadar elektrolit serum sebelum dan sesudah kemoterapi induksi remisi tanpa membedakan kelompok risiko. Untuk seluruh uji statistik, dinyatakan bermakna secara statistik apabila nilai $p<0,05$.

\section{HASIL}

Dari 34 pasien anak baru dengan leukemia limfoblastik akut yang diikutkan dalam penelitian ini berumur rata-rata 3,6 tahun ( 0,9 tahun) dan sebagian besar adalah laki-laki $(55,9 \%)$. 
Hanya leukemia limfoblastik akut tipe L-1 dan L-2 yang diikutkan dalam penelitian ini, sedangkan tipe L-3 tidak diikutkan dalam penelitian ini karena untuk terapinya tidak menggunakan Indonesia Protocol-ALL 2006 melainkan protokol Limfoma Burkitt. Berdasarkan pengelompokan faktor-faktor risiko, sebagian besar pasien termasuk di dalam kelompok risiko tinggi yaitu sebanyak $23(82,4 \%)$ pasien (Tabel 1$)$.

Tabel 1. Karakteristik subjek penelitian

\begin{tabular}{lcc}
\hline Karakteristik subjek & $\begin{array}{c}\text { Jumlah } \\
(\mathrm{n}=34)\end{array}$ & $\%$ \\
\hline Rata-rata umur (tahun) & $3,6 \pm 0,9$ & \\
Laki-laki & 19 & 55,9 \\
Perempuan & 15 & 44,1 \\
Tipe LLA & 28 & 82,4 \\
LLA L-1 & 6 & 17,6 \\
LLA L-2 & & 32,4 \\
Kelompok risiko & 11 & 67,6 \\
Risiko standar & 23 & \\
Risiko tinggi & & \\
\hline
\end{tabular}

Hasil pemeriksaan hematologi sebelum dilakukan kemoterapi induksi remisi menunjukkan keadaan anemia ringan $(\mathrm{Hb}=10,8 \quad 0,4 \mathrm{~g} / \mathrm{dL}$ ), leukositosis (hitung leukosit = $23.48631 .455 / \mathrm{mm} 3$ ) dan trombositopenia (hitung trombosit $=54.741 \quad 11.103 / \mathrm{mm} 3$ ). Hasil pemeriksaan hematologi sesudah kemoterapi induksi remisi hanya menunjukkan gambaran trombositopenia ringan (hitung trombosit $=139.284 \quad 10.254 / \mathrm{mm} 3)($ Tabel 2). Perbedaan parameter hematologi tersebut menunjukkan adanya perbaikan sesudah kemoterapi induksi remisi.

Tabel 2. Perbedaan gambaran hematologi sesudah kemoterapi induksi remisi

\begin{tabular}{lcc}
\hline \multirow{2}{*}{ Parameter hematologi } & \multicolumn{2}{c}{ Induksi remisi kemoterapi } \\
\cline { 2 - 3 } & Sebelum $(\mathrm{n}=34)$ & Sesudah $(\mathrm{n}=34)$ \\
\hline Kadar hemoglobin $(\mathrm{g} / \mathrm{dL})$ & $10,8 \pm 0,4$ & $13,2 \pm 0,7$ \\
Hitung leukosit $\left(/ \mathrm{mm}^{3}\right)$ & $23.49 \pm 31.46$ & $9.76 \pm 1.47$ \\
Hitung trombosit $\left(/ \mathrm{mm}^{3}\right)$ & $54.74 \pm 11.10$ & $139.28 \pm 10.26$ \\
\hline
\end{tabular}

Hasil pengukuran kadar elektrolit serum yang terkumpul menunjukkan bahwa sesudah kemoterapi induksi remisi terjadi penurunan kadar kalsium serum, serta peningkatan kadar kalium dan fosfat serum. Kadar kalium serum rata-rata sesudah kemoterapi induksi remisi $(4,22$ $0,53 \mathrm{mg} / \mathrm{dL}$ )

dibandingkan sebelum kemoterapi $(4,13 \quad 0,59 \mathrm{mg} / \mathrm{dL})$ menunjukkan peningkatan secara bermakna $(p=0,035)$, dan hanya terdapat 2 dari 34 pasien $(5,8 \%)$ yang menjadi hiperkalemia sesudah kemoterapi. Demikian juga dengan kadar fosfat serum rata-rata sesudah kemoterapi induksi remisi $(5,490,83 \mathrm{mg} / \mathrm{dL})$ menunjukkan peningkatan secara bermakna $(p=0,039)$ dibandingkan sebelum kemoterapi $(5,440,86 \mathrm{mg} / \mathrm{dL})$, dan ditemukan 3 dari 34 pasien $(8,8 \%)$ yang menjadi hiperfosfatemia sesudah kemoterapi. Kadar kalsium serum rata-rata sesudah kemoterapi induksi remisi $(9,120,69 \mathrm{mg} / \mathrm{dL})$ menunjukkan penurunan secara bermakna $(p=0,008)$ dibandingkan sebelum kemoterapi yaitu $(9,18 \quad 0,70$ $\mathrm{mg} / \mathrm{dL}$ ), dan keadaan hipokalsemia ditemukan pada 5 dari 34 pasien $(14,7 \%)$ sesudah mendapat kemoterapi (Tabel 3).

Hasil pemeriksaan tambahan menunjukkan bahwa kadar asam urat dan ureum plasma sesudah kemoterapi induksi remisi meningkat, tetapi tidak bermakna secara statistik. Peningkatan kadar asam urat plasma sesudah kemoterapi induksi remisi $(3,221,12 \mathrm{mg} / \mathrm{dL})$ menunjukkan peningkatan yang tidak bermakna secara statistik ( $p=$ 0,062 ) dibandingkan sebelum kemoterapi induksi remisi $(3,191,14 \mathrm{mg} / \mathrm{dL})$. Demikian juga dengan kadar ureum plasma sesudah kemoterapi induksi remisi $(7,83$ 1,50 $\mathrm{m} / \mathrm{dL}$ ) menunjukkan peningkatan yang tidak bermakna secara statistik $(p=0,212)$ dibandingkan sebelum kemoterapi induksi remisi (7,80 1,51 mg/dL).

\section{DISKUSI}

Data yang terkumpul menunjukkan bahwa 23 dari 34 $(67,6 \%)$ pasien anak dengan LLA yang menjadi subyek dalam penelitian ini termasuk dalam risiko tinggi. Beberapa laporan penelitian yang telah dipublikasi menyebutkan bahwa anak dengan LLA yang tergolong risiko tinggi memiliki risiko yang lebih besar untuk mengalami gangguan elektrolit dan metabolik, yang dapat berlanjut menjadi sindrom lisis tumor dan gagal ginjal(2,3,8,9). Meskipun angka kesintasan LLA mengalami peningkatan secara dramatis dengan kemajuan pengobatan kemoterapi, tetapi gangguan elektrolit dan metabolik dapat berpengaruh terhadap keberhasilan pengobatan(1,3). Disamping itu, gangguan elektrolit dan metabolik pada pasien anak dengan LLA juga berpotensi menimbulkan risiko, seperti halnya peningkatan efek kardiotoksik dari obat-obat sitostatika. Perubahan kadar elektrolit serum biasanya ditemukan sebelum terjadi gangguan elektrolit dan sering tanpa gejala klinis $(3,4,5)$. Analisis statistik menggunakan paired t-test, kadar elektrolit serum (kalium, kalsium, fosfat), ureum dan asam urat pada 34 pasien anak dengan LLA menunjukkan perubahan yang sangat bervariasi sesudah pemberian kemoterapi induksi remisi. Hasil analisis data menunjukkan bahwa terdapat peningkatan yang bermakna pada kadar kalium serum sesudah kemoterapi induksi remis. Peningkatan kadar kalium serum dapat ditemukan pada saat diagnosis LLA ditegakkan, yang disebabkan oleh akumulasi kalium akibat nefropati atau gagal ginjal karena infiltrasi sel leukemia ke ginjal dengan/tanpa leukostasis yang menyebabkan insufisiensi mikrovaskular.Peningkatan kadar kalium serum yang bermakna setelah kemoterapi induksi remisi menunjukkan bahwa telah terjadi lisis sel-sel leukemia akibat obat-obat sitostatika sehingga terjadi pelepasan ion kalium yang memberikan dampak perubahan secara bermakna terhadap kadar kalium serum $(2,3,5)$.

Peningkatan kadar fosfat serum pada pasien LLA terkait dengan pelepasan ion fosfat yang biasanya terkait dengan pelepasan ion fosfat yang berlebihan akibat lisis 
Tabel 3. Perubahan kadar elektrolit serum, asam urat dan ureum plasma sesudah kemoterapi induksi remisi

\begin{tabular}{|c|c|c|c|c|}
\hline \multirow{2}{*}{ Gangguan metabolik } & \multicolumn{2}{|c|}{ Induksi remisi kemoterapi } & \multirow{2}{*}{ Nilai $p$} & \multirow{2}{*}{ C.I.95\% } \\
\hline & Sebelum $\quad(n=34)$ & Sesudah $\quad(n=34)$ & & \\
\hline Kadar kalium serum $(\mathrm{mg} / \mathrm{dL})$ & $4,13 \pm 0,59$ & $4,22 \pm 0,53$ & 0,035 & $0,006-0,175$ \\
\hline $\begin{array}{l}\text { Kadar kalsium serum } \\
(\mathrm{mg} / \mathrm{dL})\end{array}$ & $9,18 \pm 0,70$ & $9,12 \pm 0,69$ & 0,008 & $0,015-0,096$ \\
\hline Kadar fosfat serum $(\mathrm{mg} / \mathrm{dL})$ & $5,44 \pm 0,86$ & $5,49 \pm 0,83$ & 0,039 & $0,002-0,085$ \\
\hline Kadar asam urat $\quad(\mathrm{mg} / \mathrm{dL})$ & $3,19 \pm 1,14$ & $3,22 \pm 1,12$ & 0,062 & $0,001-0,069$ \\
\hline $\begin{array}{l}\text { Kadar ureum plasma } \\
(\mathrm{mg} / \mathrm{dL})\end{array}$ & $7,80 \pm 1,51$ & $7,83 \pm 1,50$ & 0,212 & $0,015-0,068$ \\
\hline
\end{tabular}

sel-sel leukemia setelah pemberian obat sitostatika (cyclosporin) atau anti jamur (amphotericin B liposomal) dosis tinggi maupun gagal ginjal akibat infiltrasi ke ginjal (10). Meskipun seluruh pasien tidak mendapatkan cyclosporin selama fase induksi remisi dan/atau amphotericin B liposomal dosis tinggi, tetapi terdapat peningkatan kadar fosfat serum secara bermakna setelah kemoterapi induksi remisi. Hasil analisis ini menunjukkan bahwa pelepasan ion fosfat akibat lisis sel-sel leukemia kemungkinan tidak hanya terkait dengan pemberian cyclosporin atau amphotericin B saja, tetapi terkait juga dengan obat-obat sitostatika lainnya $(3,4,10)$.

Hipokalsemia pada pasien LLA pada umumnya terkait dengan hipoalbuminemia, hiperfosfatemia maupun resistensi hormon paratiroid ginjal $(4,9,10)$. Terbukti dari publikasi hasil penelitian sebelumnya menunjukkan bahwa penyebab hipokalsemia adalah multifaktorial, antara lain malnutrisi, malabsorpsi,bakteremia maupun efek samping obat-obat sitostatika $(3,4,5)$. Meskipun tidak ada data kadar albumin serum dan hormon paratiroid ginjal, tetapi pada peningkatan kadar fosfat serum, hasil analisis data menunjukkan adanya penurunan kadar kalsium serum yang bermakna secara statistik $(p=0,008)$ setelah pemberian kemoterapi induksi remisi. Hasil analisis tersebut menunjukkan kemungkinan terjadinya peningkatan presipitasi kristal kalsium-fosfat di tubulus ginjal, sehingga mengakibatkan nefrokalsinosis, obstruksi urin dan deposit jaringan. Sebagai konsekuensi dari hiperfosfatemia dan presipitasi kalsium-fosfat dapat terjadi penurunan kadar kalsium serum, bahkan timbul hipokalsemia $(3,4,5,7)$.

Peningkatan presipitasi kristal kalsium-fosfat di tubulus ginjal dapat disertai dengan penurunan fungsi ginjal yang ditandai dengan adanya azotemia. Asam nukleat purin

\section{DAFTAR PUSTAKA}

1. Pearce JM and Sills RH. Childhood Leukemia. Pediatrics in Review. 2005; 26(3): 96-104.

2. Kostic G, Duric Z, Bunjevacki G, Saranac L, Mokukanevic-Golubovic L, and Kamenov B. Bone Changes, Mineral Homeostasis in Childhood Acute Lymphoblastic Leukemia. Medicine and Biology. 2004; 11(3): 123-126.

3. Filippatos TD, Milionis HJ, and Elisaf MS. Alterations in Electrolyte Equilibrium in Patients with Acute Leukemia. European Journal of Haematology. 2005; 75(6): 449-460. yang dilepas ke ruang ekstraseluler akan mengalami degradasi menjadi xantin, yang kemudian dimetabolisme menjadi asam urat. Hiperurisemia biasanya akan timbul bila katabolisme purin melebihi kapasitas ekskresi ginjal $(11,12)$. Meskipun terbukti terdapat penurunan kadar kalsium dan peningkatan kadar fosfat serum secara bermakna, tetapi hasil analisis menunjukkan peningkatan yang tidak bermakna secara statistik pada kadar asam urat dan ureum plasma.

Pada pasien LLA dengan insufisiensi ginjal akut atau kronik yang telah ada sebelumnya, terdapat kecenderungan terjadi hiperkalemia, dan bahkan disertai dengan kelainan elektrolit dan metabolik lainnya seperti hiperfosfatemia, hipokalsemia, azotemia dan hyperuricemia (13). Fenomena itu dikenal sebagai sindrom lisis tumor yang termasuk salah satu kegawatdaruratan di bidang onkologi $(13,14)$

Meskipun hasil penelitian ini menunjukkan bahwa kemoterapi induksi remisi dapat menimbulkan gangguan keseimbangan elektrolit, tetapi masih diperlukan penelitian dengan jumlah subyek yang lebih besar dan rancangan yang lebih baik sehingga dapat memberikan data yang lebih dapat dipercaya dan dapat digunakan sebagai dasar penyusunan pedoman atau rekomendasi tatalaksana pasien.

Kemoterapi induksi remisi pada anak dengan LLA menyebabkan terjadinya peningkatan kadar kalium dan fosfat serum, serta penurunan kadar kalsium serum sehingga dapat berdampak terhadap timbulnya hiperkalemia, hiperfosfatemia dan hipokalsemia. Gangguan keseimbangan elektrolit tersebut berpotensi menimbulkan efek kardiotoksik (chemotherapy-related cardiotoxic) dan nefropati yang dapat berlanjut menjadi gagal ginjal akut.

4. Milionis HJ, Bourantas $\mathrm{CL}$, Siamopoulos KC, and Elisaf MS. Acid-Base and Electrolyte Abnormalities in Patients with Acute Leukemia. American Journal of Hematology. 1999; 62(4): 201-207.

5. O'Regan S, Carson S, Chesney RW, and Drummond KN. Electrolyte and Acid-Base Disturbances in the Management of Leukemia. Blood. 1977; 49(3): 345353.

6. Huen AO. Tumor Lysis Syndrome: Review of Pathophysiology and Prevention Strategies. Clinical Oncology News. 2007; 14: 216-224. 
7. Dafnis EK and Laski ME. Fluid and Electrolyte Abnormalities in the Oncology Patients. Seminars in Nephrology. 1993; 13(3): 281-296.

8. Cairo MS and Bishop M. Tumour Lysis Syndrome: New Therapeutic Strategies and Classification. British Journal of Haematology. 2004; 127: 3-11.

9. Banday KA, Sirwal IA, Reshi AR, Najar MS, Bhat MA and Wani MM. Renal Involvement in Hematologic Neoplasia. Indian Journal Nephrology. 2004; 14: 5052.

10. Boles JM, Dutel JL, Briere J, et al. Acute Renal Failure Caused by Extreme Hyperphosphatemia After Chemotherapy of an Acute Lymphoblastic Leukemia. The Cancer Journal. 2005; 53: 2425-2429.

11. Oloomi Z. Acute Lymphoblastic Leukemia without Circulating Blasts Presenting as Severe
Hypercalcemia. Acta Medica Iranica. 2007; 45(1): 7678.

12. Todo S, Imashuku S, Iroda $\mathrm{H}$, et al. Hypercalcemia in a Case of Childhood Acute Lymphoblastic Leukemia. Japanese Journal of Clinical Oncology. 1987; 17: 357362

13. Hashemi A, Shahvazian N, Zarezade A, Shakiba M, and Atefi A. Frequency of Tumor Lysis Syndrome in Aggressive and Slow Introduction Chemotherapy in Children with ALL. Iranian Journal of Pediatric Hematology and Oncology .2005; 1(1): 19-23.

14. Sirelkhatim A, Sejnova D, Puskacova J, Subova Z, and Kaiserova E. Our Experience with Tumor Lysis Syndrome Treatment. Bratislava Medical JournalBratislavske Lekarske Listy. 2008; 109(12): 560-563. 